\title{
Library Book Theft: A Case Study
}

This article summarizes an investigation of the dimensions, possible motivations, and plausible solutions to book theft in an academic library and is based on an analysis of questionnaires returned by 380 students at Ohio State University. The results indicate students think that book theft is a spontaneous and individual act; that the primary motivation is material deprivation; and that while people feel book theft's harm is serious, the punishment should be confined to the academic realm.

\begin{abstract}
A
MAJOR IMPEDIMENT TO EFFICIENT LIBRARY USE is library book theft. As a result of such theft, libraries are forced to spend their funds on replacing stolen books rather than on expanding their collections. A 1963 report estimated that the national cost of such thefts was $\$ 5,000,000$ each year. ${ }^{1} \mathrm{~A}$ worse consequence, in the opinion of librarians and library patrons, is the denial of books to other users. ${ }^{2}$

In response to the serious nature of the problem and the lack of empirical data, a study of students at the Ohio State University was undertaken. The study was concerned with investigating the dimensions, possible motivations, and the plausible solutions to book theft in a university library setting. The purpose of this article is to summarize the findings of the study and to suggest how the results may be used in ways that would lessen this problem.
\end{abstract}

Allyne Beach is a graduate student in the Sociology Department, University of Chicago. Kaye Gapen is head of QUE (Quick Editing) in the Ohio State University Libraries, Columbus. This article is based on data gathered for Ms. Beach's honors thesis in the Department of Sociology, Ohio State University, and the full report is available as an ERIC publication (ED 125572).

\section{BACKGROUND FOR THE STUDY}

Because evidence concerning library book theft has been scanty, the study was designed to explore the total problem rather than a specific explanation of book theft. The review of the literature which formed the conceptual basis of the study thus included literature from many areas. Not only did a survey of different sources make the study more complete, it also provided the study more continuity with other research. ${ }^{3}$

The literature reviewed consisted of information and opinions compiled by librarians, university administrators and educators, security experts, and social scientists. In addition, literature dealing with theft and the social environment of the university was included to determine the effects which the university community may have on library book theft. The ideas of security systems analysts provided insights into ways in which businesses perceive and handle losses of their merchandise. Finally, the social science literature contributed analyses of the structural constraints and criminal behavior in a university setting.

In the absence of a precise model, the researcher divided the ideas and findings available in the literature into 
four parts: (1) library factors, (2) bureaucratic factors, (3) university factors, and (4) avocational crime factors. Within those areas the researcher formulated hypotheses from which the questionnaire was developed. The succeeding paragraphs present the hypotheses and, when necessary, supporting literature.

A predominant means of deterring crime suggested by criminologists is environmental design. ${ }^{4}$ Librarians have used this concept by suggesting and implementing modifications in policy and library structure. According to hypotheses stemming from the literature, librarians can curb book theft by maintaining more photocopy machines, fining book thieves, conducting publicity campaigns, employing electronic devices, or utilizing security guards. ${ }^{5}$ However, one article in this field did suggest the expense of photocopying as a motivation for book theft. ${ }^{6}$

Consideration of bureaucratic and political factors influenced the development of a second set of hypotheses. These hypotheses were derived from the results of Oliner and Manuel's study on student theft. ${ }^{7}$ They found that while students may steal for material need, they are also stealing more and more as a protest against big business. Oliner and Manuel's work gave rise to the hypothesis that students steal books in protest against big libraries, which they think resemble "big business." The research of Stern, which indicated that students do not feel their interests are considered in decision-making by faculty and administrators, suggested that bureaucratic factors may be related to book theft. ${ }^{8}$

Smigel's research, which suggested that big business is preferred over government and small business as a victim of theft, resulted in the hypothesis that books are more likely to be stolen from a large library than from a small one. ${ }^{9}$
In addition, the purpose of the library may affect the location of the theft. For example, an engineer may feel more comfortable stealing from the main library than from the engineering library, which may seem more his or her "own." The results of two studies by Poland and Lunden of theft in a college environment prompted the hypothesis that book thieves steal for kicks, that they learn methods of stealing from their friends rather than developing methods themselves, and that they view rightness or wrongness of book theft as their friends do. ${ }^{10}$

Of all the areas of literature reviewed, that on avocational crime seemed to deal most completely with the methods, the type of group support, the motivations, the definition of the crime by society, and the typical handling of the crime by the criminal justice system. Geis has defined an avocational criminal as a person who does not view him or herself as a criminal, whose major source of income is derived from activities other than crime, and who can be deterred by the prospect of being stigmatized as a criminal. Most avocational crimes are committed against property. ${ }^{11}$

One aspect of avocational crime is white collar crime. Sutherland initially defined the concept of white collar crime in the 1940s.12 His treatise on white collar crime illuminated the contrast in the way that those who have resources and those who do not are processed by the criminal justice system. His work demonstrated that, despite the enormous financial and moral cost of businesspeople committing fraud and embezzlement, the sanctions are limited to fines. Cressey has explained the white collar criminal's behavior as a response to unshareable problems. ${ }^{13}$ Quinney has submitted that professionals regulate their behavior with regard to occupational (as opposed to moral) constraints. ${ }^{14}$ 
Another facet of avocational crime is shoplifting. Cameron has described the shoplifter as one who is motivated to possess specific goods but does not have the means to attain them. She has also described shoplifters as receiving group support for their actions and ingroup instruction in techniques. ${ }^{15}$

Because the avocational crime perspective has proved useful in analyzing these types of criminal activity, the researcher investigated its use in the description of book theft. The fundamental premise was that students are of a middle class background. Second, the researcher examined the terms in which the university community defines book theft. More specifically, the researcher hypothesized that people were unsure if book theft is right or wrong and that sanctions chosen for such theft would not severely affect life chances. Third, the researcher explored the motivations of book thieves. Just as the white collar crime perspective suggests that there is pressure from status inconsistency which motivates white collar criminals to trespass the law, many librarians have suggested that library book theft is a response to academic pressure. ${ }^{16}$

The research tested the pressure by investigating whether students steal books to ensure better grades, to deal with stiff competition from their peers, to have books for their personal collections, or because they cannot afford to purchase the books. Grade point, class rank, and field of study were cross-tabulated to determine their relationship to the types of pressure. Fourth, the researcher used the shoplifting tactics proposed by Cameron to shape the hypotheses that stealers learn methods from their friends and that friends of thieves think book theft is legitimate.

Because the avocational crime perspective stimulated many hypotheses pertinent to library book theft, the framework developed to study avocational crime formed the principal con- ceptual foundation for the study. As such, library book theft was defined as the intentional removal of books from the library in an unauthorized manner. ${ }^{17}$ Library book theft appears to be a type of avocational crime. Finally, such theft may be inhibited by publicly labeling it as a crime. ${ }^{18}$

\section{METHODOLOGY}

As in most exploratory studies, the case study method was employed. A university was chosen as the site of the study because theft is a problem for academic libraries and because data can be collected easily. In an overview study of this sort, in which a number of hypotheses are being explored, it is desirable to obtain a heterogeneous sample. The library system at the Ohio State University (OSU) provided a good environment since the system has a wide variety of library materials and security systems and since the student population provides heterogeneity in respondents.

To obtain a heterogeneous sample, enrollment records of all classes in the fall quarter of 1974 were examined. Classes were selected using class rank and college as guides in order to provide a variety of people within each college. The ten classes yielded a sample size of 446 students, and, of the 446 questionnaires distributed and returned, only 66 questionnaires (14 percent) were unusable because they were answered in a haphazard manner or were incomplete. Thus the study was based on a total of 380 usable questionnaires.

Undoubtedly, a major factor in the library loss rate is employee theft. In fact, Cameron in her works on shoplifting estimates the loss rate due to employee theft at 67 percent. ${ }^{19}$ Moreover, instances of library employees stealing books have been cited in the library literature. ${ }^{20}$ Some of these concern employees abusing their check-out privileges; others deal with stealing from 
rare book collections. Bond, in his article on book store security, suggests that rapid turnover leads to theft. ${ }^{21}$ At OSU the turnover rate for both student parttime employees and civil service equivalent employees is 25 percent per year. ${ }^{22}$ Because of time and monetary limitations and because the researcher suspected that the self-reporting rate would not be as valid among library employees, this study was limited to an examination of students.

The rough draft of the questions for the questionnaire was developed following a review of the literature and a discussion with the OSU libraries' faculty who were also researching book theft. ${ }^{23}$ Two pretests resulted in the questionnaire that was finally administered. Following coding and keypunching, the results were processed by the computer software program Statistical Package for the Social Science (SPSS).

In the study the self-reporting technique was used to distinguish book thieves from those who had not stolen books from the library. That is, one question asked students how many books they had stolen from the OSU libraries. This technique was perfected in 1957 by Nye and Short ${ }^{24}$ and it has been used extensively since then. ${ }^{25}$ The most serious problem is likely to be exaggeration, which may be compounded by a person's interpretation of the question. ${ }^{26}$ In the following discussion those respondents who admitted having stolen books are described with the term "thieves"; those who did not, with the term "non-thieves."

\section{Findings}

As detailed results of the study are now available through ERIC, only general findings will be discussed here. ${ }^{27}$ First, what can we say about the sample itself? Second, what are the demographic variables for thieves and non-thieves? Third, how do the findings for thieves and non-thieves relate to the four sets of perspectives: (1) book theft in response to library structure and policy; (2) book theft as a protest against bureaucracy; (3) book theft as "kicks" or gang behavior; and (4) book theft as avocational crime?

\section{Student Sample}

A general examination of the results shows that the student sample was indeed heterogeneous on the demographic variables and was diverse with regard to fields of study. Furthermore, the sample was almost equally divided between males and females, and the class standing of the students was skewed toward more advanced students. The social-economic background of the sample was skewed toward the middle class. Finally, the principal uses respondents made of the library were for study and reference with 53 percent of the sample using the library one to three times a week and 33 percent of the sample not using the library at all.

\section{Demographic Characteristics}

For the most part, the demographic characteristics and opinions of those who admitted to book theft ( 5 percent of the sample) did not differ markedly from those who reported no theft. No time boundaries were given for the question on whether or not a respondent had stolen a book from the university library. Consequently, students could have meant that they stole a certain number of books in one year or in their entire experience at OSU.

While occupation and education were significantly related to each other, only the relationship between occupation alone and those who steal books was significant. In general, fewer of the principal wage earners in the families of those who admitted to book theft were major professionals, and more were unskilled, unemployed, or receiving some type of government benefit. 
Accordingly, the income of these families was lower, but not significantly lower, than that of the total sample. For example, 42 percent of the thieves' families earned $\$ 10,000$ to $\$ 14,999$ annually, as compared to 27 percent of the nonthieves' families. Concurrently, only 6 percent of the thieves' families earned $\$ 25,000$ or more a year, while 26 percent of the non-thieves' families earned that much.

Other relationships are of interest. For example, a greater percentage of the thieves did not receive help from their parents to meet their current educational expenses. Book thieves came most frequently from the arts and the humanities, though they did not seem to come from a particular class rank. A greater proportion of the thieves used the library for leisure reading and study during midterms and finals, although the frequency of library use did not seem to differ between the two groups. Finally, although Poland hypothesized that men steal more frequently than women, ${ }^{28}$ in this study a comparable proportion of 53 percent of the men and 47 percent of the women reported book theft.

\section{Book Theft in Response to Library Structure and Policy}

The respondents did not indicate an important motive for book theft was in not having enough time to use books in the library; and of all the motives investigated, the expense of photocopying material was commonly held to be the single most important cause of book theft. Of the several alternatives proposed by librarians for curbing book theft, installation of electronic devices or enforcement of library fine policies received the most vigorous support. A majority of students felt that having more photocopy machines, student security guards, and publicity campaigns were somewhat effective.

\section{Book Theft as a Protest Against Bureaucracy}

OSU was viewed by most students as bureaucratic. Although 74 percent liked the OSU educational system and 46 percent felt that the university administration seemed to care about the rights and privileges of students, only 10 percent felt that there was little red tape at OSU, and only 12 percent felt that they had a say in university policy. Book thieves liked the OSU educational system less than those who did not report having stolen. Thus the only significant measure dealing with bureaucratic factors was whether or not students think they have a say in university policy. This measure is similar to Stern's measure of "low student dignity." 29

Furthermore, while Smigel's hypothesis about "least risk" was supported by the opinions of the total sample, thieves were equally divided on the issue. Only 21 percent of the total sample felt that stealing from the main library would result in more guilt feeling than stealing from a department library, and 31 percent of the thieves felt there was a difference in guilt.

It seems, therefore, that students did not think protest against OSU as a "big business" was a strong motivation for book theft. Although people perceive OSU as bureaucratic, this is not felt to be a factor stimulating book theft.

\section{Book Theft as "Kicks" or Gang Behavior}

Few respondents in the total sample and even fewer of the thieves felt "kicks" to be a motivation for book theft. Similarly, the hypothesis that book theft is a gang type of behavior was unsupported in this research. Despite the fact that thieves and nonthieves view book theft as wrong, a greater proportion of those who had not stolen felt that the act is illegal and should be punished. Furthermore, thieves were uncertain about how their 
friends view book theft. The strongest indication that the hypothesis about gang behavior is inappropriate is the fact that only 25 percent of the thieves said that they had learned methods for stealing from their friends.

\section{Book Theft as Avocational Crime}

People who admitted they stole books came from a slightly lower middle-class background compared to the middleclass background of the total sample. This relationship is logical from the avocational crime perspective that material deprivation is a principal pressure motivating people to steal. A significant relationship existed between those who perceived material deprivation as a reason to steal books and those who were less severe in punishing the person represented in the appropriate hypothetical vignettes provided in the questionnaire.

Both thieves and non-thieves felt library book theft is wrong. But fewer thieves felt the act is illegal and deserves punishment. The occupation of the parent was significantly related to a person's perception of the severity of book theft. Respondents whose parents were ranked as medium and small professionals were less severe. In addition, the perception of the crime was significantly related to the perceived opinion of family and friends. A greater proportion of the thieves were uncertain about the opinions of their friends and felt that their parents' opinion was not so negative as that of the entire sample. In particular, the fact that the attitude of the "best friend" was uncertain and that the thief developed methods of stealing on his or her own makes the comparison between book theft and shoplifting not as strong as hypothesized. Cameron has indicated that ingroup instruction and group support are essentials of shoplifting. ${ }^{30}$

\section{Summary}

This research has clarified the motiva- tions leading to, methods of, and ways to curb library book theft. It has demonstrated that the total sample perceived library book theft as wrong. In fact, almost one-half of the sample felt the act is illegal and should be punished. As expected, thieves did not define book theft as negatively as did non-thieves.

There was revealed a discrepancy between thieves' and non-thieves' estimates of dollar loss each year to the university due to library book theft. The average estimate made by the total sample was $\$ 56,000$, while the average estimate made by thieves was $\$ 18,000$. Both thieves and non-thieves did agree, however, that book theft is wrong principally because it hinders the academic achievement of their fellow students. Students felt that library book theft deserves punishment, but the majority of these students chose a punishment which would hinder specifically the academic pursuits rather than the entire life of the book thief, for example, taking away library privileges for a year.

The choice of punishment by the students combined with the fact that students perceive the harm done by book theft as deprivation of the academic community of its resources indicates that students view book theft as an academic crime only.

This study does indicate that material deprivation is the major motive for stealing books. Neither thieves nor nonthieves were very supportive of the motivation derived from Oliner and Manuel's hypothesis that book theft is done in protest against the university's bureaucracy and resemblance to "big business," nor from Lunden's hypothesis that it is done for kicks. Poland's hypothesis that theft among college students resembles gang behavior seems inappropriate with regard to book theft, principally because it is thought to be a spontaneous act, using a method 
which the thief develops alone.

In this study, bureaucratic factors did not influence book theft. The total sample felt there was less risk in stealing from a large library than from a small one, but thieves were divided on the issue. Furthermore, perception of guilt did not seem to play a major role in choice of location for library theft. When a difference in guilt was perceived by the respondents, the thieves, unlike those in the total sample, perceived less guilt in stealing from department libraries than from the main library.

Occupation of parents and use of the library were the demographic variables which yielded a significant difference between thieves and non-thieves. More thieves were in the lower portion of the middle-class categories than non-thieves. Such a fact tends to support the explanation that material deprivation or "relative deprivation" is a major motivation for book theft. Although the relationship is not significant, more of the thieves were dependent on themselves to meet current educational expenses.

The demographic variables of class rank or field of study did not significantly affect the amount of academic pressure. Parenthetically, a greater portion of thieves were in the field of arts and humanities. However, a greater number of juniors said that the pressures of good grades and stiff competition were a motivation for book theft. A greater number of social and behavioral science, professional, and business administration students felt that stiff competition was a motivation for book theft. Social and behavioral science students felt the pressure of good grades more than those in other fields.

That electronic devices represent an effective means of curbing book theft was felt by 51 percent of the total sample and by 68 percent of the thieves. The effectiveness of electronic devices was supported not only by the opinion of respondents but by actual fact in the OSU libraries. The OSU commerce library conducted an inventory in 1973 and found 4 percent of the year's new books to be missing. A second inventory in 1974, after the installation of electronic devices, revealed that the loss rate had dropped to .65 percent.

Publicity campaigns were not thought to be effective for the most part by the students. Publicity campaigns have been shown to be effective only during the period in which they are being conducted. Although both thieves and nonthieves thought books are taken by hiding them in clothing or putting them in a satchel or purse, student security guards were not thought to be an effective means of limiting book theft.

Given the factors affecting book theft, it seems apparent that the avocational crime perspective yields the best tool for analysis of this phenomenon. The fact that the thieves perceive their "best friends" as uncertain rather than as approving of book theft weakens the analogy with shoplifting, but the definition of the crime and the motivation of material deprivation suggest that the avocational crime perspective is appropriate.

As with any study, results depend on the conceptualization of the questions asked. Because the literature dealing with book theft is rudimentary, such conceptualization is necessarily fragmentary and the resulting questions may also be unrefined and imprecise.

While the small number of reported thieves may be an accurate index of participants in book theft, the small sample size does make any generalizations less firm. The technique of the study is another limitation. Because the questionnaire method does not allow indepth investigation, some aspects of this study may require more thorough attention. Finally, it is unknown whether the students who comprised this case study 
are representative of patrons of other university libraries or other non-academic libraries.

Despite such limitations, the results did clarify some elements of book theft, and the concluding section discusses the implications of several alternatives suggested by this research: (1) redefine book theft in legal and criminal terms; (2) invest in duplicate and replacement copies; and (3) invest in an electronic book theft detection system.

\section{Alternatives}

\section{Book Theft as a Crime}

Although the parallels between shoplifting and book theft are not as strong as hypothesized, this research suggests that the motivations, the direction of group support, and the tone of the definition of library book theft by other members of the community resemble what researchers have found to be characteristic of shoplifting. Since the act of book theft and the severity of its definition are similar to shoplifting, perhaps the methods which have been suggested to curb shoplifting are applicable here.

Because of the ambiguous sentiments that some people hold about the legality of shoplifting, many authors have advised that proprietors and law enforcement officials be more rigid and harsh in their treatment of shoplifters. Individuals from various areas and disciplines have counseled that security guards be given power to arrest shoplifters and that shoplifters be prosecuted. ${ }^{31}$ If book theft and shoplifting are analogous, perhaps viewing book theft as a violation against the state as well as against university rules and regulations would be effective.

In view of the fact that the value of a stolen book would generally be less than $\$ 150$ (a misdemeanor in Ohio), one might question if police would give high priority to such a crime. In gener- al, thefts of items of lesser value have higher clearance rates than others. ${ }^{32}$ Still, police officials may wonder if book theft-a crime which even to the academic community has not been worthy of being criminalized-is worth the time that they would have to take from their other responsibilities for court attendance or completing necessary paperwork.

Just as the police may be hesitant in processing library book theft, so may the library administration be hesitant in spending the money and time necessary to prosecute the criminal. A study by Stark and Cohen, which examined who is prosecuted and why, indicates that the shoplifters prosecuted are those who have stolen the most valuable articles and those who are unemployed..$^{33}$ Would the library prosecute someone who stole an average book that, including processing cost, would be worth $\$ 37$ ?

\section{Replacement and Duplicate Copies}

A study undertaken in the OSU libraries in 1972 indicated that of missing books in the collections other copies of the same title were available for 58 percent, other editions of the same title were available for 9 percent, and no other copies or editions were available for 33 percent. $^{34}$ If one assumes that the current loss rate is 6 percent of each year's acquisitions, then in 1975-76 in the OSU libraries 3,050 volumes of the total acquired (50,830 volumes) would be lost. Of this group there would be no duplicate copies or editions for 1,006 volumes (33 percent).

The estimated cost in the library in 1976-77 for a monograph is $\$ 22$, plus a processing fee of $\$ 15$. Thus it would be necessary to expend $\$ 37,222$ to replace only those monographs for which no other copies or editions are available. Replacement of the entire group of 3,050 missing volumes would cost an estimated $\$ 112,850$.

There is also the possibility of initial- 
ly providing duplicate copies. In 197576 , for example, the OSU libraries added 8,880 duplicate copies to the collections. The estimated cost of these duplicates (at $\$ 15$ per volume) was $\$ 133,200$. Additionally, the libraries spent $\$ 5,000$ to $\$ 10,000$ for the replacement and duplication of high-use materials. Before theft, therefore, the libraries have invested more than $\$ 138$,000 in attempting to provide sufficient copies for the system's users.

\section{Electronic Theft Detection Systems}

A third alternative is an electronic theft detection system. The OSU libraries, as a case in point, have installed electronic theft detection systems in the main library, the commerce library, the fine arts library, the music library, and the education library. The initial cost for these five systems (including sensitized materials for insertion in 205,000 volumes) was $\$ 81,328$, or $\$ 20,607$ per year, if prorated for each of the first five years.

Very rough estimates were made for staff time spent in conjunction with this detection system, including time for inserting sensitized material in books, sensitizing and desensitizing them, and dealing with library users when the alarm sounds. Costs (using the minimum student hourly wage of $\$ 2.20$ ) were estimated at $\$ 39,000$ per year.

For each of the first five years of operation, therefore, the detection system would cost $\$ 20,607$ for equipment and material and $\$ 39,000$ for personnel activities, or a total cost of $\$ 59,607$. Approximately one-third of the OSU libraries are thus covered, and to protect the entire library system, $\$ 178,821$ would be required.

After an amortization period of five years, the detection system for the five libraries presently covered would cost each year an estimated $\$ 3,822$ for the sensitized material and $\$ 39,000$ (without allowance for wage increases) for per- sonnel activities, a total of $\$ 42,822$. The annual cost for the total library system on this basis would be approximately $\$ 128,466$.

Although the alternatives of a detection system or replacement and duplication of copies are amenable to cost analysis, there are limitations to this analysis. First, time estimates and costs are not firm, with many of the figures estimates based on rough samples or opinions. Second, it is difficult to know which figures to compare. While theft detection systems are initially expensive, the operation of a book theft detection system could cost less than the replacement of stolen copies or the purchase of multiple copies. In addition, staff costs to support electronic systems might be considered equal to the staff time presently being spent on searching for stolen copies, rather than calculated as an additional cost. Third, the analysis of neither of these alternatives takes into consideration the time spent or the frustration felt by library users who are trying to locate books which have been stolen.

Protagonists of electronic theft detection devices believe that, regardless of the cost, the devices at least ensure a book on the shelves (or a circulation record) when a user of the library requests a certain title. Protagonists of replacements and duplicate copies may argue that money spent on theft detection systems could better be spent on acquisitions important to build up the collection.

\section{ConcLusion}

The results of this study are a beginning step in understanding what motivates people to steal books from academic libraries. Because the problem has not been analyzed exhaustively, librarians continue to face the dilemma of what they can do to prevent book theft. As with any research, the results of this project can be used in establishing li- 
brary policy and in planning future research concerning academic libraries and book theft.

The study did demonstrate, however, that library book theft is a spontaneous and individual act. Furthermore, the results suggest that the primary motivation for book theft is material deprivation. While respondents to the questionnaire felt that the harm was serious, the punishment, they believed, should be confined to the academic realm. The possibility of defining book theft as a public crime might involve more prob- lems than libraries and colleges and universities would wish to face.

The analysis of the other alternatives -duplication and replacement of copies or a theft detection system-is in some ways incomplete. For example, the analysis did not include the cost of staff time presently expended in attempting to locate stolen books, the effects of a book theft detection system on the minds and emotions of users, or a change in circulation patterns before and after the installation of an electronic detection system.

\section{REFERENCES}

1. Protecting the Library and its Resources: A Guide to Physical Protection and Insurance. Report on a Study Conducted by Gage-Babcock \& Associates, Inc. (Chicago: Library Technology Project, American Library Assn., 1963), p.21.

2. Maxine Reneker, "Book Theft in Academic Libraries" (Master's thesis, University of Chicago, 1970): Allyne Beach, "Library Book Theft: A Case Study" (Undergraduate honors thesis, Dept. of Sociology, Ohio State University, 1976). Available in ERIC database: ED 125572.

3. For a discussion on constructing hypotheses in a new area of research, see Frank Westie, "Toward Closer Relations Between Theory and Reason: A Procedure and an Example," American Sociological Review 22:150-54 (Spring 1957).

4. Oscar Newman, Defensible Space (New York: Macmillan, 1972); Jeffery C. Ray, Crime Prevention Through Environmental Design (Beverly Hills: Sage Publications, 1971).

- 5. Reneker, "Book Theft"; Ernest A. Savage, "Buy, Borrow, or Steal: Thieves' Methods," Library Journal 84:141-45 (1959); Mary Quick, "A Proposed Program for Reducing Book Losses" (Master's thesis, Western Michigan University, 1964); Barbara L. Feret, "Point of Sale," Wilson Library Bulletin 47:46-47 (1972); John N. Berry, "To Catch a Thief," Library Journal 90: 1617-21 (1965); Perry D. Morrison, "Lost Book Campaign in Sacramento," Wilson Library Bulletin 40:526-29 (1966).

6. Robert F. Clark and G. Haydee, "Your Charging System: Is It Theft-Proof?" $\mathrm{Li}$ brary Journal 91:642-43 (1966).

7. S. P. Oliner and Maurice Manuel, "Student Theft: Crime or Protest," Humboldt Journal of Social Relations, p.27-35 (1973).
8. George G. Stern, "Studies of College Environments" (ERIC Document Reproduction Services, ED 010647, 1966).

- 9. Erwin Smigel, "Attitudes Towards Stealing Related to Size of Victim Organization," in Erwin Smigel and H. Lawrence Ross, eds., Crime Against Bureaucracy (New York: Van Nostrand Reinhold, 1970), p.15-27.

10. Stephen G. Poland, "Characteristics, Behavior, and Attitudes of Male College Students Who Have Committed Theft" (Ph.D. dissertation, Purdue University, 1971); Walter A. Lunden, "Shoplifting Among College Students" (Ames, Iowa: Iowa State University of Science and Technology, 1966).

11. Gilbert Geis, "Avocational Crime," in Daniel Glaser, ed., Handbook of Criminology (Chicago: Rand McNally, 1974), p.273.

12. Edwin H. Sutherland and Donald R. Cressey, Principles of Criminology (7th ed., Philadelphia: Lippincott, 1966).

13. Donald R. Cressey, Other People's Money: A Study in the Social Psychology of Embezzlement (Glencoe: Free Press, 1953).

14. Earl R. Quinney, "Occupational Structure and Criminal Behavior: Prescription Violation by Retail Pharmacists," Social Problems 2:179-85 (1963).

15. Mary Owen Cameron, The Booster and the Snitch: Department Store Shoplifting (New York: Free Press, 1964).

16. Reneker, "Book Theft"; Rita A. Schefrin, "The Barriers to and Barriers of Library Security," Wilson Library Bulletin 45:870-78 (1971); Norman Vinnes, "A Search for Meaning in Book Theft," Scholastic Librarian 18:25-27 (1969); Lee Zimmerman, "Pilfering and Mutilating Books," Bookmark 13:5-9 (1960). 
17. H. Green, "Analysis of Literature Dealing With Vandalism as Indexed in Library Literature 1953-63" (Master's thesis, Atlanta University, 1964).

18. Geis, "Avocational Crime," p.273.

19. Cameron, The Booster and the Snitch.

20. "ALA Asks Victimized Libraries to Contact Special Committee," Library Journal 89: 1574 (1965); "Librarians Guilty of Stealing, Purloining and Converting Federal Property on Loan to Library," Library Journal 94:2400 (1969).

21. William Bond, "Eleven Steps Can Lead You to Curtailing Inventory Losses and Crime in the Campus Bookstore," College and University Business 54:53 (1973).

22. Interview with Rita Hirshman, Personnel Office of the Ohio State University Libraries, 1975.

23. "Book Losses in Libraries, a Pilot Opinion Survey," a study in progress by Kaye Gapen, Nancy Keller, Susan Miller, and Robert Daugherty, the Ohio State University Libraries.

24. F. Ivan Nye and James F. Short, "Scaling Delinquent Behavior," American Sociological Review 22:325-31 (1957).

25. Savera Trangri and Michael Schwartz, "Delinquency Research and Self-Concept Variable," Journal of Criminal Law, Criminology, and Police Science 58:182-90
(1967); John P. Clark and Larry L. Tift, "Polygraph and Interview Validation of Self-Reported Deviant Behavior," American Sociological Review 31:516-23 (1966); Leroy C. Gould, "Who Defines Delinquency: A Comparison of Self-Reported and Officially Reported Indices of Delinquency for Three Racial Groups," Social Problems 16:325-26 (1969).

26. Roger G. Hood and Richard Sparks, Key Issues in Criminology (New York: McGraw-Hill, 1970), p.46-70.

27. Beach, "Library Book Theft: A Case Study."

28. Poland, "Characteristics, Behavior, and Attitudes."

29. Stern, "Studies of College Environments."

30. Cameron, The Booster and the Snitch.

31. Ibid.; Bond, "Eleven Steps," p.53.

32. Jonathan Rubinstein, City Police (New York: Farrar, Strauss and Giroux, 1973; Ballantine Books, 1973), p.363.

33. L. E. Cohen and R. Stark, "Discriminatory Labeling and Five Finger Discount: An Empirical Analysis of Differential Shoplifting Dispositions," Journal of Research in Crime and Delinquency 11:25-39 (1974).

34. "A Computer-Aided Analysis of Lost Books at the Ohio State University Libraries" (Columbus: Ohio State University Libraries, 1972). 